\title{
The Correct Use of Images with Child Protection in Sport
}

\author{
Özgün PARASIZ1 ${ }^{1}$, Alperen HALICI ${ }^{*}$ (D) , Mustafa Yaşar ŞAHIN ${ }^{1}$ (D) \\ ${ }^{1}$ Gazi University, Faculty of Sport Sciences, Ankara, Turkey.
}

Original Article

Received: 02.04.2021
Accepted: 21.05.2021
DOI: $10.25307 /$ jssr.908730

Online Publishing: 30.06 .2021

\begin{abstract}
The aim of this research is to produce a study that will guide sports clubs and organizations to use photos and videos without harming and abuse children and to prepare regulations for the correct usage of images in child sports. In this study, document analysis technique from the qualitative research methods was used. For this purpose, the relevant regulations and practices of major national and international sports organizations which has implementation about child safeguarding in sports were examined in terms of general situation, basic principles, risks and measures in the usage of photography and video. Regulations on correct usage of photography and video of 16 different sports organizations from England, Ireland, the United States of America, Australia and New Zealand were included. The obtained data were analyzed using descriptive analysis method. The findings show that in the use of photography and video policies implemented by national and international sports organizations, precautions are taken to ensure that permission is sought from parents to use children's images, that personal information of children is not included in image sharing, and that inappropriate angles in photographs and video shoots are avoided. Finally, these policies ban the recording of images in locker rooms, health rooms etc. and it is forbidden to enter these areas with phones etc. that can record images.
\end{abstract}

Keywords: Image, Child protection in sports, Photograph and video usage.

\section{Sporda Çocuk Koruma Kapsamında Görüntülerin Doğru Kullanımı}

\section{$\ddot{O} z$}

$\mathrm{Bu}$ araştırmanın amacı, spor kulüp ve organizasyonlarının çocuklara zarar vermeden ve istismar etmeden fotoğraf ve video kullanmalarına rehberlik edecek bir çalışma üretmek ve çocuk sporlarında görsellerin doğru kullanımına yönelik düzenlemeler hazırlamaktır. Nitel araştırma yöntemlerinden belge analizi tekniğinin kullanıldığı çalışmada İngiltere, İrlanda, Amerika Birleşik Devletleri, Avustralya ve Yeni Zelanda'dan 16 farklı spor organizasyonunun sporda çocuk koruma ile ilgili yönetmelik ve uygulamaları, fotoğraf ve video kullanımında genel durum, temel ilkeler, riskler ve önlemler açısından incelenmiştir. Elde edilen veriler betimsel analiz yöntemi kullanılarak analiz edilmiştir. Bulgular, ulusal ve uluslararası spor örgütleri tarafından uygulanan fotoğraf ve video politikalarında, çocukların görsellerinin kullanılması için ebeveynlerden izin alınması, görüntü paylaşımlarında çocukların kişisel bilgilerine yer verilmemesi ve fotoğraf ve video çekimlerinde uygunsuz açılardan kaçınılması gerektiğini göstermektedir. Ayrıca bu politikalar soyunma odaları, sağlık odaları gibi yerlerde görüntü kaydı yapılmasını ve bu alanlara telefon gibi görüntü kaydedebilen araçlarla giriş yapılmasını yasaklamaktadır.

Anahtar Kelimeler: Görsel, Sporda çocuk koruma, Fotoğraf ve video kullanımı.

\footnotetext{
* Corresponding Author: Res. Assist. Alperen Halıc1, E-mail: alperenhalici@ gazi.edu.tr
} 


\section{INTRODUCTION}

The ability of a society to develop and progress in all directions is determined by the development of the children who will shape its future in terms of physical, social and spiritual aspects. The most effective and important tool in children's social, mental, physical and moral development is sports (Brackenridge, Kay \& Rhind, 2012; Brackenridge \& Rhind, 2014; Mountjoy et al., 2016; Parasız, Şahin \& Çelik, 2015). However, alongside all the individual and social benefits that sport offers, it also appears to foster opportunities for abuse due to its unique nature (Farstad, 2007; Parent \& Demers, 2011). In a sports environment, children and young athletes can be subjected to words and behaviors that may disrupt their mental health and development whether through their trainers, coaches or managers, either willingly or unwittingly (Brackenridge \& Telfer, 2010; Brackenridge et al., 2012; Halıc1, Parasız \& Şahin, 2019; Mountjoy et al., 2016; Rhind, McDermott, Lambert \& Koleva, 2015). As stated in Article 31 of the United Nations (UN) Convention on the Rights of the Child, the International Charter for Physical Education and Sports published by UNESCO in 1978 and Article 4 of the basic principles of Olympism published by the International Olympic Committee (IOC): 'it is the right of every child and the responsibility of the States parties to play sports and play in safe and suitable environments'.

Starting from this point, the United Kingdom and other European Union countries and many developed countries such as Australia, USA, Canada and even some African countries made arrangements, based on these legal bases, for all stakeholders of sports, especially coaches, managers and parents by establishing "Child Protection Systems in Sports" among the sports managing public institutions, sports federations, sports clubs and all sports organizations where children participate (Boocock, 2002; Parasiz et al., 2015). The importance of child protection to prevent, detect and report child abuse cases in all kinds of sports organizations where children participate, has become increasingly recognized in sports programs.

We are said to be living in the age of technology and communication. In a study on Internet use in 2019, it was determined that $57 \%$ of the world population uses the internet and $45 \%$ uses social media (Wearesocial, 2019). Along with the development and reduction in cost of communication technologies, the increasing use of social media and the desire to appear on social media have led to many factors that pose significant risks for children (Lilley, 2016). The most important of these risks is that all kinds of people can contact and communicate with children through social media and the Internet, without the control of their parents and that cautiously shared posts can lead to difficult situations to compensate for.

Sports clubs, sports federations and organizations use photographs and videos to promote and celebrate their athletes, events, announcements, and achievements. Some coaches also use photos and videos as a training method to support their athletes' skill development. However, the use of such photographs and videos and sharing them on websites and social media can pose significant direct and indirect risks for children if not managed properly. For example, these images can be used by child abusers as a means of reaching children easily. The visual information can be used by the abuser to establish a relationship of trust with the child, leaving the child vulnerable. Photographs taken from unsuitable angles and places can cause harm to the child, for example when it leads to cyberbullying. In addition, a shared image without taking 
into account the basic principles of child protection in sports can cause significant emotional damage that can last for many years (Chase \& Statham; 2005; CPSU, 2017). Just as photos and videos were first invented, the use of images in children's sports can be black and white. An image which is not used in the framework of child protection in sports standards can cause to child abuse and show its black face. But a properly use of images can produce profit and snow white results by serving promotion, incentive or even educational purposes.

For this reason, in order to protect children from all kinds of risks in all sports activities in which children participate, it has become mandatory to establish standards for collecting, recording and using images. These policies do not aim to eliminate or complicate communications that are designed to promote sport or celebrate sport achievements but rather, suggest a set of standards to reduce the risk of children being harmed through photography and video.

Accordingly, many international and national sports organizations who have implemented child protection in sports systems, especially in the UK, have set policies and standards for the use of photography and video. The aim of this research is to produce a study that will guide sports clubs and organizations to use photos and videos without harming and abuse children and to prepare regulations for on the correct use of images in child sports.

\section{METHOD}

Document analysis technique, one of the qualitative research methods, was used in this study, which was conducted to evaluate the policies and regulations of sports organizations regarding the use of photography and video. The regulations and practices of sports organizations were chosen from England, Ireland, the United States of America, Australia and New Zealand. While selecting these countries, it has been taken into account that safeguarding in sports practices and policies are common and that safeguarding in sport systems are functional (Lang and Hartill, 2015). In this context, regulations on correct usage of photography and video of 16 different sports organizations were included. Due to the saturation of the research data, the study was limited to 16 regulations. Descriptive analysis method was applied to the obtained findings. The findings were coded separately by the researchers, and the themes were reached by combining the obtained codes according to their common features.

Based on the findings obtained within the scope of the study, the relevant policies are basically divided into two parts: the first part covers the use of photographs and videos for athletes and the basic principles to be followed regarding the collection process of the visuals; the second part provides guidelines regarding visual content and the sharing process of that content. Under the theme of the process of collecting images; policy making, parent and child Permission, official determination, prohibited areas, and parents' responsibility were included. Under the theme of the sharing process, no descriptive information, suitable angles, appropriate clothing, and image, focusing on activity, visual security were included. The themes and codes were explained and interpreted in relation to each other and results were obtained. The themes created as a result of the analysis were examined, criticized and approved by two instructors working at the Faculty of Sport Sciences of Gazi University. 


\section{FINDINGS}

Within the scope of child protection in sports, it is observed that countries such as England, USA, Canada and Australia but also many national and international sports organizations, sports federations, sports clubs and non-governmental organizations have established comprehensive policies and have put various principles and rules in place for the use of photographing and videoing child athletes.

Based on the findings obtained within the scope of the study, the relevant policies are basically divided into two parts: the first part covers the use of photographs and videos for athletes and the basic principles to be followed regarding the collection process of the visuals; the second part provides guidelines regarding visual content and the sharing process of that content.

\section{Image collection process}

\section{Policy making}

When the related policies of the sports organizations are required examined, it is observed that it is necessary to establish policies for sharing photos and videos and to inform everyone who comes into contact with children about these policies in order to eliminate risks (Arsenal, 2014; City Football, 2015; CPSU, 2017; England Football Association, 2019; England Table Tennis, 2017; Swim Ireland, 2016; United Kingdom Athletics, 2009; USA Gymnastics, 2017;). For example, the United Kingdom Athletic Association (2009) states that 'All athletics clubs and district associations should develop a policy on the use of children's images on their websites and other publications'.

\section{Parent and child permission}

In child protection sports policies, the most important factor to be considered before the use of photographs or videos of children is the need to obtain permission from parents and children for the sharing of visuals. In this regard all sports organizations should create a photo and video use approval form so that consent can be obtained from both the child and the parent. Information on where, for what purpose and how long the images will be used should be included in the approval form (Arsenal, 2014; Australian Sports Commission, 2019; Basketball İreland, 2013; British Gymnastics, 2009; CPSU, 2017; England Football Association, 2019; FIBA Oceania, 2014; Hockey Australia, 2015; Ireland, 2013; New Zealand Volleyball, 2018; Swim Ireland, 2016; USA Gymnastics, 2017; USA Swimming, 2019). For example, the International Oceania Basketball Federation (2014) states the obligation to 'obtain informed consent from the child and parent or guardian of the child before photographing or filming a child'. The Australian Sports Commission (2019) expressed a similar view in its policies as 'Permission must be obtained from the athlete's parent before the photos are published. Make sure they are aware of what purpose the image will be used for'. Furthermore, the Child Protection in Sport Unit (CPSU) of UK (2017) states if parents do not approve of the use of the images, it is the responsibility of the sports clubs are responsible to take the necessary precautions to avoid taking a close-up picture of those children. 


\section{Official determination}

Another issue to be considered in the use of photographs and videos of children is the process of determining who will be responsible for the recording of these visuals. Child protection sports policies state that the individuals who will record the visuals during a sport event should be determined beforehand and that these individuals should be informed about the appropriate standards and contents in the photography and video recording, within the framework of child protection in sports policies. Such a policy should also state that all visuals taken remain the property of the organization, cannot be used for any other purpose (notably, they cannot be sold) and that confidentiality should be ensured (Chelsea, 2016; CPSU, 2017; England Football Association, 2019; England Table Tenis, 2017; FIBA Oceania, 2014; Gymnastics Victoria, 2015). For example, the policy of England Football Association (2019) states that 'If you are commissioning a professional photographer, clearly state your expectations. Provide a clear summary of what is appropriate in terms of content and behavior. Inform them about your club's commitments to protect children and youth and determine who will keep the recorded visuals and what they want to do with them'.

\section{Prohibited areas}

Such policies will also specify the areas and places where images can or cannot be taken. Pursuant to these policies, photographs and video recordings are not allowed in private areas such as toilets, locker rooms, etc. where athletes have privacy (Arsenal, 2014; Australian Sports Commission, 2019; Chelsea, 2016; City Football, 2015; CPSU, 2017; England Football Association, 2019; Hockey Australia, 2015; Swim Ireland, 2016; USA Gymnastics, 2017). For example, the Ireland Swimming Association (2016) prohibits photography and video recording in areas such as toilets, dressing rooms, physical therapy rooms. In addition, the Australian Sports Commission (2019) states in its relevant policies that photographs, and video recordings should not be taken outside the venue or at an athlete's home.

\section{Parental responsibility}

Within the scope of photograph and video policies, parents of the child athletes also have some responsibilities. The child and parent have the right to decide on whether they consent to the taking of photographs and video recording and then to how they are used. For this reason, parents are required to inform their sports clubs as to whether their child consents to the recording and then publishing of the images (Arsenal, 2014; Australian Sports Commission, 2019; Basketball Ireland, 2013; British Gymnastics, 2009; City Football, 2015; England Football Association, 2019; FIBA Oceania, 2014; Hockey Australia, 2015; New Zealand, 2018; Swim Ireland, 2016; USA Swimming, 2019). The US Swimming Federation (2019) policies explain this as 'A parent or guardian has a right of refuse to have children photographed. For this reason, before posting the photo, parental consent should be received, preferably in writing'. There are also cases where it is forbidden to take any images in line with witness protection, child custody, etc. and it is stated as the responsibility of the parent to report such situations to the sports organization.

There are also limitations on the use of images that parents are allowed to take at sports events and inside organizations. Parents are allowed to photograph from the audience areas but not 
allowed to take pictures from the competition area (Victoria, 2006). The Irish Basketball Federation, on the other hand, states that the audience or parents should first obtain permission from the club for any visual shoot. In related policies, parents are told not to share images that contain personal information about their or others' children on social media and that they are responsible for the negative consequences that may arise due to the sharing of these images (CPSU, 2017).

\section{Content and sharing process of images}

As well as following the basic principles and methods in the process of collecting visuals in child protection policies in sports, sports organizations should also take provide information about the kind of content that is permissible and the process of sharing the visual content.

\section{No descriptive information}

Regarding the sharing or publishing of visual content related to sports activities and organizations in which children participate, almost every policy highlights the need to avoid including personal and descriptive information about the children. Thus, the inclusion of descriptive information such as children's full name, phone numbers, addresses, hobbies etc. is explicitly prohibited in most sports organization policies (Australian Sports Commission, 2019; FIBA Oceania, 2014; Arsenal, 2014; Chelsea, 2016; City Football, 2015; England Football Association, 2019; England Table Tennis, 2017; Hockey Australia, 2015; Swim Ireland, 2016; United Kingdom Athletics, 2009; USA Swimming, 2019). For example, their child protection policy, Chelsea football club (2016) states that 'No images of children featured in Club publications will be accompanied by personal details such as their home address' while the Australian Hockey Federation (2015) requests that 'When using images, avoid typing the name of the athlete. If this is not possible, avoid using the first and last name together'. CPSU (2017), on the other hand, states that a child's name can be used in exceptional situations, where it is in the child's benefit or if the child or parent give their permission.

\section{Suitable angles}

One of the most common standards with regards to the content of visuals related to the sports activities and organizations of child athletes is that they should be taken from appropriate angles. In this regard, it is expressly forbidden by many sports organizations to shoot visuals from image angles that are prone to misinterpretation and misuse, such as bending forward, opening legs (CPSU, 2017; Gymnastics Victoria, 2015; Swim Ireland, 2016; USA Gymnastics, 2017). In its policy, the American Gymnastics Federation (2017) has banned the sharing of visuals in which the genital area is prominent.

\section{Appropriate clothing and image}

The need to avoid visuals that may adversely affect children features in the policies of many sports organizations (Arsenal, 2014; City Football, 2015; CPSU, 2017; England Football Association, 2019; FIBA Oceania, 2014; Gymnastics Victoria, 2015; United Kingdom Athletics, 2009; USA Gymnastics, 2017). This does not just pertain to visual angles but also to what the athletes might be wearing. To reduce the risk of inappropriate use of images, some organizations stipulate that only images of players with suitable apparel (tracksuits or 
competition suits) can be used (British Gymnastics, 2009; CPSU, 2017; FIBA Oceania, 2014; England Football Association, 2019; Swim Ireland, 2016). FIBA Oceania (2014) includes this in its policy as follows: 'Children should be adequately clothed and not in poses that could be seen as sexually suggestive'. Additionally, the England Football Association (2019) policy states that images of athletes wearing jewelry despite being against the rules should not be used.

\section{Focus on activity}

Another prominent guideline regarding the content of the visuals is the requirement to focus on the activity rather than the children when recording images of children doing sports (Australian Sports Commission, 2019; Arsenal, 2014; CPSU, 2017; England Football Association, 2019; England Table Tennis, 2017; Swim Ireland, 2016; USA Gymnastics, 2017; United Kingdom Athletics, 2009).

The sports policy of the CPSU (2017) in this regard is as follows: 'Activities such as swimming, gymnastics and athletics present a higher risk for potential misuse than others; therefore, instead of showing the entire body and face of children, these activities should use visuals in the water and focus on the activity rather than a particular child'. The wording in the United Kingdom Athletic Federation (2009) policy is as follows: 'Try to focus on the activity rather than a specific child and use photos that represent the broad mass of children involved in athletics as much as possible'.

\section{Visual security}

Another important consideration is the safe storage of images after the recording and use of children's images are also among the important issues (Australian Sports Commission, 2019; Arsenal, 2014; CPSU, 2017; England Football Association, 2019; United Kingdom Athletics, 2009). In order to ensure that photographs and video recordings of children doing sports do not end up in the hands of unauthorized individuals, the UK Child Protection in Sport Unit (2017) emphasizes the need to keep photographs and video recordings of children in a safe environment. Accordingly, it is stated that visuals should not be stored in unencrypted portable devices such as laptops, memory cards or mobile phones. The Australian Government (2019) has ruled that the direct copying of images by another source should be restricted.

\section{DISCUSSION}

This document analysis shows that many national and international sports organizations, but particularly sports organizations of developed countries such as England, Canada, Australia, New Zealand, USA, etc. have policies regarding the sharing of photographs and video footage within the scope of child protection in sports. The analysis shows that the findings can be classified into two categories: the process of collecting the images and the content and the process of sharing the images.

In terms of the content of the policies for sharing photographs and video footage of children playing sports, all organizations that offer sports activities in which children participate need 
to have a policy in place. As stated in Article 3 of the United Nations (UN) Convention on the Rights of the Child, "parties are responsible for developing appropriate guiding principles to protect child against information and documents that may harm the child's well-being". Therefore, every sports organization needs to have such policies in place and needs to ensure that all staff, volunteers, audience, children and parents are aware the policy.

According to the findings, permission must be obtained from parents and children before images are collected. To this end, many sports organizations have created a detailed photo and video use approval form. The content of this form includes information on where, for what purpose and for how long the photograph and/or video recording will be used. Collecting and sharing images without permission may in some cases put children in a difficult and even dangerous situation. For example, sharing the image of a child in local authority care may have particularly damaging consequences as their may be legal restrictions due to domestic violence or s/he may be a witness in criminal proceedings (CPSU, 2017; England Football Association, 2019). In addition, a parent may not want their child's image to be used as an advertising medium.

In its recommendation on Children's Rights in the Digital World (2018), the Council of Europe has also indicated the need for parental consent. Specifically, it states that the 'processing of personal data should only be possible with the clear and informed consent of children and/or their parents or legal representatives'. In Article 8 of the European Union General Data Protection Regulation, there are regulations regarding the processing of data pertaining to people under the age of 16 . According to this regulation, in order to publish visuals of children under the age of 16, permission must be obtained from the person who has custody rights over the child. When looked specifically at the Republic of Turkey; In Article 5 of the Law on the Protection of Personal Data, there is a provision that "Personal data cannot be processed without the express consent of the data subject". In addition, according to Article 10, it is stated that the data controller is obliged to inform and information should be given about the purpose for which the data will be used. For this reason, it is imperative for sports organizations to have an approval form so that consent can be obtained formally from children's parents before the taking of any photographs and/or video recordings.

Based on this analysis, it is clear that policies regarding photography and video use within sports organizations forbid the recording of images in some areas of sports facilities and activities. So for example, images cannot be taken in areas such as toilets, dressing rooms and physical therapy rooms. In addition, care must be taken that with images taken from angles that might be misinterpreted and therefore misused, such as bending forward or opening legs, positions that arise due to the nature of the sport. These policies are important as part of the prevention of cyber-bullying that children can be subjected to in the internet environment. Studies show that a central cyber-bullying tool, defined as deliberate harmful behavior using electronic devices (Baker \& Kavşut, 2007), is photography and video (Aslan \& Doğan, 2017; Baker \& Kavşut, 2007; Kalender, Keser \& Tugun, 2019; NCH \& Tesco Mobile, 2005). For example, one in ten children who participated in a research study conducted by $\mathrm{NCH}$ (2005) stated that their pictures were taken by phone and $17 \%$ of them were sent to others. In research carried out by Baker and Kavşut, $8 \%$ of the participants stated that they were cyberbullied through photography. Feelings of depression, low self-esteem, fear, self-indulgence, etc. can 
be experienced more intensely in children who are victims of cyber bullying (Baker \& Kavşut, 2007; Kalender et al., 2019). Also, recorded images can be used by malicious people to force a child into unwanted sexual activity (CPSU, 2017). For this reason, sports organizations have the responsibility to take the necessary precautions in order to protect child athletes by showing the necessary sensitivity in sharing photos and videos.

One of the most important factors to be considered in the process of sharing visuals that any information that might identity the child needs to be removed. Thus, many sports organizations prohibit any information about a child, including full name, phone numbers, school and home addresses, hobbies, phobias, etc. when sharing visual content with the child's full name, phone numbers, school and home addresses, hobbies, phobias, etc. According to a study conducted in 2004, children were questioned about personal information: $70 \%$ stated that they would share personal information on the internet to win a prize and $46 \%$ reported having previously released information to a person they had met online (Dombrowski, Gischlar \& Durst, 2007). Giving personal information may cause children to be subjected to the type of abuse called "grooming". Grooming is defined as the abuse of children whom abusers meet in a virtual environment in a process and them in a virtual or real world (Bükre, Özlem \& Deniz, 2017; Chase \& Statham; 2005; NSPCC, 2019; Wurtele \& Kenny, 2016). In grooming, the aim is to prepare the child for the abuse process by gaining their trust (Brackenridge \& Fastina, 2005; Bükre et al., 2017; Gönültaş, 2016). The abuser learns what children like and dislike, are concerned about and fear and uses this knowledge to persuade the child to engage in sexual intimacy (Gönültaş, 2016). According to an earlier study on 202 child victims' forensic notifications (Gönültaş, 2013), almost 70\% of the children had undergone a certain process (deception, bribery, promises, etc.) by the perpetrator before the abuse began. According to the data of NSPCC, more than 5,000 grooming cases took place in England and Wales between September 2017 and March 2019. Reference to grooming appears in the policy of the Australian Hockey Federation (2015) 'We will not provide information about the child's hobbies, interests, school and such, because this information can be used by pedophilia or other people as a grooming tool'. England Football Federation (2019) also makes reference to grooming, stating that giving descriptive information of child athletes can be used as a grooming tool. Clearly, any personal information that is provided when sharing the images of child athletes can make the child identifiable. The abuser who has obtained descriptive information can then use this to gain the trust of the child, making the abuse of that child easier. It is therefore important not to include children's personal information in the content of photograph and video sharing.

Ensuring that images are stored securely after recording is also an aspect that is specified in the policies of photography and video use which were analyzed for this research. According to the European Union General Data Protection Regulation, the data controller must take security measures in order to prevent possible risks to the data. Indeed, sports organizations have a legal obligation to take necessary measures such as keeping children's photos and video recordings in a safe environment and reducing direct copying in order to ensure the safety and privacy of children's images. 


\section{CONCLUSION}

The research findings have determined that many of the world's leading national and international sports organizations have policies regarding photographs and videos of child athletes and their usage, within the framework of the child protection in sports.

Analysis of international policies shows that these policies are generally described as having two dimensions including the process of collecting the images and the content and the process of sharing the images.

\section{As the basic principles related to the process of collecting the visuals:}

- Requesting permission from parents to take and use images,

- Informing parents about how, where and for what purpose the images can be used,

- Determination of the individuals who will take the visual shots,

- Informing the officials about appropriate standards and contents when taking photographs and videos.

- Not allowing the taking of pictures of the athletes in privacy areas such as toilets and locker rooms or entry into these areas with devices that record images.

\section{Regarding the Content and Sharing Process of the Images;}

- Focusing on the activity rather than the children during the event,

- Taking care to record the visuals from appropriate angles,

- Avoiding visuals that may adversely affect children's image,

- Ensuring the privacy and security of photograph and video recordings,

- Not including descriptive or personal information of children when sharing visuals sharing.

The measures explained above for the use of photography and video take place within the organizational hierarchy in the form of a pyramid structuring, which is a characteristic feature of sports organization. Therefore, child protection policies in sports determined by international sports federations and the policies related to the use of photography and video within these policies, actually concern the federations and clubs of all member states of these federations. Therefore, it should be mandatory for any sports organizations to take measures regarding the sharing of photographs and videos and to implement a policy related to them within the framework of the general policies of their state and the principles of the international sports organizations to which it is affiliated.

\section{Declaration of Conflicting Interests}

The author declared no potential conflicts of interest with respect to the research, authorship, and/ or publication of this article.

\section{Authors' contributions}

$\mathrm{AH}$ and ÖP analyzed the data and was primarily responsible for writing the manuscript. MYŞ was involved in conceptualization of the project, writing, and reviewing the final manuscript. All authors read and approved the final manuscript. 


\section{REFERENCES}

Arsenal Football Club (2014). Safeguarding children and young people policy \& procedures. https://www.arsenal.com/sites/default/files/documents/Safeguarding_Children_and_Young_1.pdf, Date of access:12.02.2019.

Aslan, A. \& Doğan, Ö. B. (2017). Çevrimiçi şiddet: Bir siber zorbalık alanı olarak "potinss" örneği [Online violence: The case of "potinss" as a cyber-bullying space]. Marmara Iletişim Dergisi, 27, 95-119. https://doi.org/10.17829/midr.20172729524.

Australian Sports Commission (2019). Guidelines on the use of images of children. http://websites.sportstg.com/get_file.cgi?id=2409780, Date of access:15.02.2019.

Baker, E. Ö. \& Kavşut, F. (2007). Akran zorbalığının yeni yüzü: siber zorbalık [Cyber bullying: a new face of peer bullying]. Eurasian Journal of Educational Research (EJER), 27, 31-42.

Basketball Ireland (2013). Basketball Ireland code of ethics for children's sport. https://www.dlbb.ie/Documents/pdfs/basketball-ireland-code-of-ethics-for-childrens-sport.pdf, Date of access:12.12.2019.

Birleşmiş Milletler Çocuk Haklarına Dair Sözleşme [The United Nations Convention on the Rights of the Child] (1990). https://www.unicefturk.org/public/uploads/files/UNICEF_CocukHaklarinaDairSozlesme.pdf, Date of access:12.02.2019.

Boocock, S. (2002). The child protection in sport unit. Journal of Sexual Aggression, 8(2), 99-106. https://doi.org/10.1080/13552600208413342.

Bostancı, N., Albayrak, B., Bakoğlu, İ. \& Çoban, Ş. (2006). Üniversite öğrencilerinde çocukluk çağı travmalarının depresif belirtileri üzerine etkisi [The effects of childhood traumas on depressive symptoms in university students] New Symposium Journal, 44(2), 189- 95

Brackenridge, C. \& Fasting, K. (2005). The grooming process in sport: Narratives of sexual harassment and abuse. Auto/Biography, 13(1), 33-52.

Brackenridge, C. H., Kay, T. \& Rhind, D. (2012). Sport, children's rights and violence prevention: A source book on global issues and local programmes. London: Brunel University Press.

Brackenridge, C. H. \& Rhind, D. (2014). Child protection in sport: Reflections on thirty years of science and activism. Social Sciences, 3(3), 326-340. https://doi.org/10.3390/socsci3030326.

Brackenridge, C. H. \& Telfer, H. (2010). Child protection and sports development. B. Houlihan and M. Green (Ed.), In Routledge Handbook of Sports Development (pp. 467-479). London: Routledge.

British Gymnastics (2009). Safeguarding \& protecting children policy. http://www.bginsurance.org/Portals/0/Documents/Safeguarding\%20and\%20Protecting\%20Children\%2 OPolicy-2009.pdf, Date of access:12.12.2019.

Bükre, Ç., Özlem, S. \& Deniz, Ç. (2017). Adı: Meraklı, soyadı: Çocuk, durum: Çevrimiçi, sonuç: Grooming, internette çocuk istismarı [Curious, surname: child, situation: online, conclusion: grooming, online child abuse]. Journal of Current Pediatrics/Guncel Pediatri, 15(3), 87-97.

Chase, E. \& Statham, J. (2005). Commercial and sexual exploitation of children and young people in the UK-A review. Child Abuse Review, 14, 4-25. https://doi.org/10.1002/car.881.

Chelsea Football Club (2016). Safeguarding children policy \& proedures. https://prod-content cdn.chelseafc.com/content/dam/documents/Misc/Chelsea\%20FC\%20\%20Safeguarding\%20Children\% 20Policy.pdf, Date of access:12.02.2019.

Child Protection in Sport Unit (CPSU) (2017). Photography. https://thecpsu.org.uk/helpadvice/topics/photography/, Date of access:15.02.2019.

City Football (2015). Group safeguarding policy and mandatory guidance. https://www.melbournecityfc.com.au/sites/mcy/files/201807/Group\%20Safeguarding\%20Policy\%20\% 281\%29.pdf , Date of access:16.12.2019. 
Dombrowski, S. C., Gischlar, K. L. \& Durst, T. (2007). Safeguarding young people from cyber pornography and cyber sexual predation: A major dilemma of the Internet. Child Abuse Review, 16(3), 153-170. https://doi.org/10.1002/car.939.

England Football Association (2019). Celebrating football through photographs and video. http://www.thefa.com/football-rules-governance/safeguarding/best-practice-downloads, Date of access:15.02.2019.

England Table Tennis (2017). Photographyand use of cameras/videos including mobile phones guidelines. https://tabletennisengland.co.uk/wp-content/uploads/2016/02/photography-guidelines-january-issuetwo.pdf, Date of access: 15.02.2019.

European Union (2018). Recommendation of the committee of ministers to member states on guidelines to respect, protect and fulfil the rights of the child in the digital environment. https://search.coe.int/cm/Pages/result_details.aspx?ObjectId=09000016808b79f7, Date of access: 15.02.2019.

Farstad, S. (2007). Protecting children's rights in sport: the use of minimum age. Human Rights Law Commentary, $3,1-20$.

FIBA Oceania (2014). FIBA Oceania child protection policy. http://websites.sportstg.com/get_file.cgi?id=3091976, Date of access:15.02.2019.

General Data Protection Regulation (2016). https://eur-lex.europa.eu/legalcontent/EN/TXT/PDF/?uri=CELEX:32016R0679, Date of access:17.02.2020.

Gönültaş, B. M. (2013). Çocuğa yönelik cinsel şiddet olaylarında olay kurgusunda ve şüpheli ifadelerindeki ortak özelliklerin incelenmesi [The examination of common features of suspects' expressions and the construction of sexual violence cases against children]. Yayınlanmamış Doktora Tezi, İstanbul Üniversitesi Adli Tıp Enstitüsü, İstanbul.

Gönültaş, B. M. (2016). Cinsel istismarcıların çocuklara yaklaşım metot ve teknikleri [Modus operandi of sexual abusers and their grooming techniques]. Zeitschrift für die Welt der Türken, 8(1), 289-305.

Gymnastics Victoria (2015). Photographic and filming policy. http://gymnastics.org.au/images/vic/About\%20Us/Policies/15XX_Photographic\%20Policy\%202015_0 1.pdf, Date of access:15.02.2019.

Halıcı, A., Parasız, Ö. \& Şahin, M. Y. (2019). Sporda çocuk istismarı türlerinin sınıflandırllması [Classification of child abuse types in sports]. 3. Akademik Spor Araştırmaları Kongresi (300-310), Batum.

Hockey Australia (2015). Hockey Australia limited (ha) member protection policy. http://membership.hockeyvictoria.org.au/wp-content/uploads/2019/10/2015-Hockey-AustraliaMember-Protection-Policy-V9-FINAL.pdf, Date of access:10.12.2019.

Kalender, M. K., Keser, H. \& Tugun, V. (2019). Ortaokul ve lise öğrencilerinin siber zorbalık görüşleri, deneyimleri ve müdahale davranışları [Middle and high school students' opinions, experiences and responses regarding to cyberbullying]. Eğitim ve Bilim, 44, 183-200. http://doi.org/10.15390/EB.2019.7820.

Kişisel Verilerin Korunması Kanunu [Turkish Personal Data Protection Law] (2016). Kanun No: 6698, Sayı: 29677, Cilt: 57.

Lang, M. \& Hartill, M. (2015). Safeguarding, child protection and abuse in sport: international perspecives in research, policy and practice. New York: Routledge.

Lilley, C. M. (2016). The role of technology in managing people who have been convicted of internet child abuse image offences. Child Abuse Review, 25(5), 386-398. https://doi.org/10.1002/car.2444.

MacAuley, D. (1996). Child abuse in sport. British Journal of Sports Medicine, 30(4), 275-276. https://doi.org/10.1136/bjsm.30.4.275-a. 
Mountjoy, M., Brackenridge, C., Arrington, M., Blauwet, C., Carska-Sheppard, A., Fasting, K. \& Starr, K. (2016). International Olympic Committee consensus statement: Harassment and abuse (non-accidental violence) in sport. British Journal of Sports Medicine, 50(17), 1019-1029. https://doi.org/10.1136/bjsports-2016096121.

NCH ve TESCO Mobile (2005). Putting $u$ in the picture mobile bullying survey 2005. https://www.bienestaryproteccioninfantil.es/imagenes/tablaContenidos03SubSec/mobile_bullying_repo rt.pdf, Date of access:15.12.2019.

New Zealand Volleyball (2018). Child protection policy. https://www.volleyballnz.org.nz/media/attachments/2018/09/03/vnz-child-protection-policy-2018-12.pdf, Date of access: 08.12.2019.

NSPCC (2019). Over 5,000 online grooming offences recorded in 18 months. https://www.nspcc.org.uk/what-wedo/news-opinion/over-5000-grooming-offences-recorded-18-months/, Date of access: 08.12.2019.

NSPCC. What is grooming? https://www.nspcc.org.uk/what-we-do/news-opinion/over-5000-grooming-offencesrecorded-18-months/, Date of access:17.12.2019.

Parasız, Ö., Şahin, M. Y. \& Çelik, A. (2015). Sporda çocuk koruma programı uygulamaları: İngiltere örneği [Child protection program implementations in sport management]. International Journal of Science Culture and Sport (IntJSCS) 3, 2148-1148. https://doi.org/10.14486/IJSCS329.

Parent, S. \& Demers, G. (2011). Sexual abuse in sport: a model to prevent and protect athletes. Child Abuse Review, 20(2), 120-133. https://doi.org/10.1002/car.1135.

Rhind, D., McDermott, J., Lambert, E. \& Koleva, I. (2015). A review of safeguarding cases in sport. Child Abuse Review, 24(6), 418-426. https://doi.org/10.1002/car.2306.

Swim Ireland (2016). Filming and photography policy. http://www.swimireland.ie/files/documents/Filming-andPhotography-Policy-April-2016.pdf, Date of access: 15.02.2019.

United Kingdom Athletics (2009). Guidelınes for the use of photographic \& video images of children/young people under the age of 18. https://www.uka.org.uk/governance/policies/use-of-photographic-videoimages-of-children-young-people-under-the-age-of-18/, Date of access:15.02.2019.

USA Gymnastics (2017). USA gymnastics safe sport policy. https://usagym.org/PDFs/safesport/policy.pdf, Date of access:10.12.2019.

USA Swimming (2019). Model photography policies. https://www.usaswimming.org/docs/default-source/safesportdocuments/club-toolkit/1.-policies-and-guidelines/model-policy_photography.pdf, Date of access: 15.02 .2019 .

Weare (2019). The Global state of digital in October 2019. https://wearesocial.com/blog/2019/10/the-global-stateof-digital-in-october-2019, Date of access:13.12.2019.

Wurtele, S. K. \& Kenny, M. C. (2016). Technology-Related sexual solicitation of adolescents: a review of prevention efforts. Child Abuse Review, 25, 332-344. https://doi.org/10.1002/car.2445.

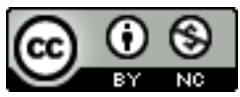

Except where otherwise noted, this paper is licensed under a Creative Commons Attribution 4.0 International license. 